\title{
Examination of Urban Landscape Aesthetics through Mapping Using Geotagged Social Media Data from Flickr
}

\author{
Wantong Zhao*, Wei Han \\ School of Humanities and Arts, Xidian University, Xi'an, China \\ Email: *zhaowt@stu.xidian.edu.cn
}

How to cite this paper: Zhao, W. T., \& Han, W. (2021). Examination of Urban Landscape Aesthetics through Mapping Using Geotagged Social Media Data from Flickr. Current Urban Studies, 9, 66-82. https://doi.org/10.4236/cus.2021.91005

Received: December 11, 2020

Accepted: February 6, 2021

Published: February 9, 2021

Copyright $\odot 2021$ by author(s) and Scientific Research Publishing Inc. This work is licensed under the Creative Commons Attribution International License (CC BY 4.0).

http://creativecommons.org/licenses/by/4.0/

(c) (i) Open Access

\begin{abstract}
Landscapes are part of the earth's surface, and include terrestrial, aquatic, natural, and anthropogenic features with differing dominance. The evaluation of Landscape Aesthetics (LA) and scenery is helpful for the understanding landscapes. The mapping of LA is increasingly being recognized in urban and landscape planning. Examining the flow and capacity of LA is an essential element in understanding the sustainability of urban landscapes. An explicit methodological approach was proposed for mapping LA using social media data (geolocated photographs) from Flickr to study the spatial distribution of LA in Xi'an, China. The LA flow and LA capacity were conceptually distinguished and assessed. The LA flow was analyzed with 10,278 geotagged photographs from Flickr to express people's actual appreciation of LA. The LA capacity was examined by spatial criterion evaluation, combined the weight of landscape features. LA flow and LA capacity differ in both spatial extent and quantity, although there was a spatially explicit balance between them. The results show that LA flow largely occurs in the urban core zone and that LA capacity is concentrated in certain parts of Xi'an due to the imbalanced distribution of historical cultural heritage sites. This research contributes to a better understanding of LA values and the relationships between LA values and landscape characteristics. The results can support the integration of cultural services in landscape planning and land use policy.
\end{abstract}

\section{Keywords}

Landscape Aesthetics, Mapping, Social Media Data, Social Value

\section{Introduction}

Aesthetics can be defined as the sensory or sensory-emotional values of people's 
immediate and intuitive perceptions (Lazdāne et al., 2013; Langemeyer et al., 2018). They also can reflect humans' understanding and appreciation of landscapes by combining historical and cultural identities (Nogué \& Vicente, 2004). Landscape perception has become the key process for connecting humans with ecological phenomena (Gobster et al., 2007). People are powerfully and regularly engaged by aesthetic experiences evoked through their perception of the landscape. However, aesthetics goes beyond art appreciation or sublime experience (Saito, 2007). The evaluation of the aesthetic quality of a landscape is influenced by assessment standards (Jorgensen, 2011). It makes people acquire what social value of Landscape Aesthetics (LA) and meaning in the context of LA and recognize as a LA experience. The value of LA has been addressed more in socioecological research, besides in the public perception (Howley, 2011).

LA has been valued in many studies based on direct and indirect valuation approaches. The conventional methods for assessing LA include hedonic pricing valuation (Estruch-Guitart \& Vallés-Planells, 2015), contingent valuation (Dupras et al., 2018), revealed preference techniques (Kong et al., 2007) and stated preference techniques (Poder et al., 2016). Estruch-Guitart and Vallés-Planells (2015) estimated the total economic value of the LA in Albufera Natural Park (Valencia, Spain) using the analytical multicriterion valuation method with the aid of a set of experts. Van Riper et al. (2012) collected and analyzed on-site and mailback survey data to measure the social value and natural resource conditions in Hinchinbrook Island National Park, Australia. Zhang et al. (2019) obtained social value data from questionnaires in Taibai Mountain National Forest Park and used the ecosystem service model to evaluate the social value of the Qinling Mountains. Schirpke et al. (2019) aimed to evaluate the historic development of aesthetic values from a perception survey using 10,536 observer points and calculated landscape characteristics for each observer point using a regression model. These studies used limited samples to express people's perceptions of the environment around them and cannot provide spatial information. To understand cross-cultural and continent-scale landscape values, LA assessments must rely on fragmented, diverse and biased cases (van Zanten et al., 2014). Social media data can overcome the abovementioned challenges associated with mapping landscape values. The use of social media data to study societally relevant questions across large-scale geographic extents is novel (van Zanten et al., 2016).

Social media data are produced and used to exchange information via texts, images or videos generated by the users on virtual community platforms (Cui et al., 2018a). Different types of data can be captured by various social media platform sensors. Particularly, social media sites support geotagged information submission and sharing and the platforms amass a large amount of spatiotemporal data. There is a large amount of unexplored information, providing a special perspective on the evaluation and quantification of aesthetic values. Lee and Son (2018) used text mining methodologies to assess the perceptions of the 
Taean Coast National Park embedded in text uploaded to the "Taean Travel" blogpost. Cui et al. (2018b) studied social media and mobility landscapes with social media data using a three-step methodological framework to uncover the spatial patterns of urban human mobility. It has been shown that social media data are very useful for analyzing various types of content out an expert's point of view, and can be used to analyze various aspects of how people perceive and enjoy landscapes by integrating landscape objects, images and activities.

Flickr, a popular photo-sharing social network, has a large number of user-generated digital photos. Each uploaded photo that expresses aesthetic values can supply several kinds of data, including visual content, geolocation data, an observed date and a description (Spyrou \& Mylonas, 2016). Tenkanen et al. (2017) systematically assessed park popularity and temporal visitor counts in 56 national parks in Finland and South Africa from Flickr photographs with high-precision visitor statistics. Langemeyer et al. (2018) used social media data from Flickr to map the spatial distribution of the LA of the cultural ecosystem services and enhance their consideration in land use policies and landscape planning. Van Zanten et al. (2016) evaluated the usefulness of Flickr and quantified the landscape values in Europe on a continental scale. Figueroa-Alfaro and Tang (2017) used geotagged photographs from Flickr and ArcGIS software to examine the spatial patterns of the aesthetic value of cultural ecosystem services in Nebraska. These researchers mapped and explained where specific landscape values occur. Their results considered the different stakeholders and land use groups and revealed place-specific perceptions, attitudes and preferences. Furthermore, individually perceived landscape values were spatially aggregated and the diversities among people, communities and places were also revealed. Ginzarly et al. (2019) proposed a diversity of methods to visualize specific behavioral patterns and landscape perceptions based on social networking platforms. The results can improve the understanding of the diversity of heritage sites and attributes for decision-making processes in heritage site planning and management. Oteros-Rozas et al. (2018) found a positive (albeit weak) relationship between landscape diversity and cultural ecosystem service diversity by analyzing 1,404 photos from the Flickr and Panoramio platforms. Social networking platforms offer a novel opportunity for researchers to collect large-scale diversity data. Spatial patterns can be used to measure and value the distribution and diversity of LA using social media data. These data and methods have potential to operationalize and allow their mainstream use in landscape management and environmental decision-making.

To assess the current LA value of Xi'an, geotagged Flickr photographs of Xi'an were used to identify and map LA values, both as an evaluation of the method and as a case study in China. To better understand LA, LA flow and LA capacity were conceptually distinguished and determined. LA flow is identified as the actual realization of benefits through landscape appreciation on a point in time and space (Villamagna et al., 2013; Langemeyer et al., 2018). LA flow assessment 
has been used in aesthetic and cultural ecosystem service evaluation, although it has not historically been done with geotagged social media data (Pastur et al., 2016; Plieninger et al., 2013; Richards \& Friess, 2015; Yoshimura \& Hiura, 2017). LA capacity is an expression of physical landscapes and their features or landscape diversity (Langemeyer et al., 2018) and helps to inform land use or land change policies. Moreover, the relationships between LA flow and LA capacity can provide information for land use decision-making (Baró et al., 2016). In this study, assessing and mapping LA flow and LA capacity is particularly relevant. Urbanization impinges upon the capacity of landscapes to provide sustained LA flows, and the high density of the human population and human assets usually results in high demands for LA. This assessment delivers key information for landscape planning in Xi'an and helps to directly and indirectly improve the level of regional landscape services.

\section{Material and Methods}

\subsection{Case Study}

Xi'an, which is located in northwestern of China and is the capital of Shaanxi Province, is used as an example in this study and located at the northwest of China. The city has a total area of $10,096 \mathrm{~km}^{2}$ with a resident population of 9.6 million people (Xi'an Statistical Yearbook, 2018). Xi'an, which has a history of more than two thousand years and recognized as one of the most important cities in China, was the capital of 13 dynasties and the eastern starting point of the Silk Road. Xi'an has a rich physical heritage and intangible cultural heritage, and these characteristics increase public awareness. The length and breadth of Xian's historical legacy has an iconic status in both the domestic and international tourism markets. Figure 1 shows the studied areas and the main attractions of Xi'an found in the Flickr data. The main attractions are depicted in Table 1.

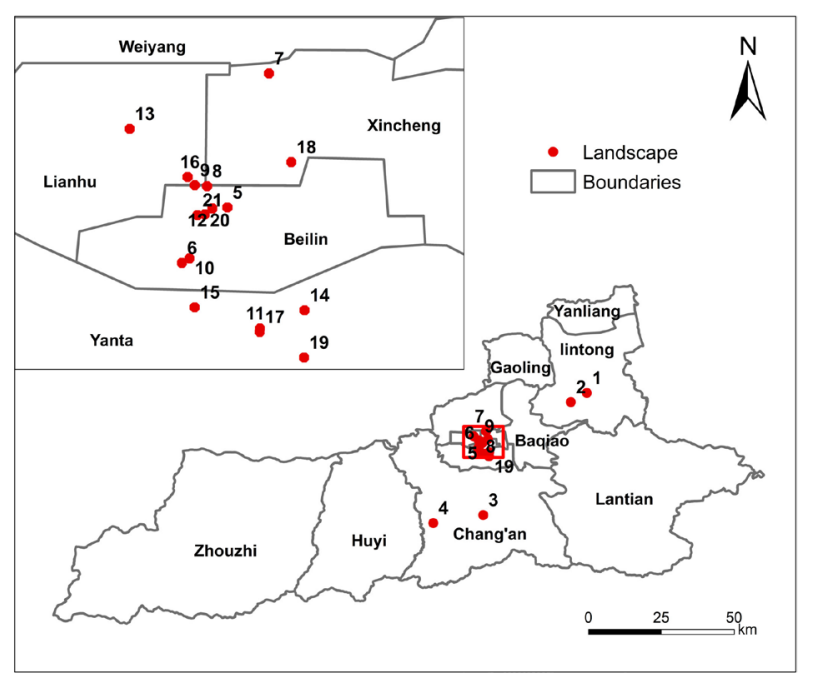

Figure 1. An overview of the study area and the main attractions of Xi'an in the photographs from Flickr. 
Table 1. The main attractions of Xi'an analyzed in this study (Zhao et al., 2018).

\begin{tabular}{|c|c|c|}
\hline Attraction No. & Attraction & Topic \\
\hline 1 & Emperor Qinshihuang's Mausoleum Site Museum & Cultural relics \\
\hline 2 & Hua Qing Palace & Cultural relics \\
\hline 3 & Guanzhong Folk Art Museum & Cultural relics \\
\hline 4 & Ancient Guanyin Monastery & Cultural relics \\
\hline 5 & Stele Forest Museum & Cultural relics \\
\hline 6 & Xi'an Museum & Cultural relics \\
\hline 7 & Daming Palace & Cultural relics \\
\hline 8 & Bell Tower & Cultural relics \\
\hline 9 & Drum Tower & Cultural relics \\
\hline 10 & Small Wild Goose Pagoda & Cultural relics \\
\hline 11 & Giant Wild Goose Pagoda & Cultural relics \\
\hline 12 & Shuyuan Gate & Cultural relics \\
\hline 13 & GuangRen Lama Temple & Cultural relics \\
\hline 14 & Qinglong Temple & Cultural relics \\
\hline 15 & Daxingshan Temple & Cultural relics \\
\hline 16 & Great Mosque of Xi'an & Cultural relics \\
\hline 17 & Ci'en Temple & Cultural relics \\
\hline 18 & Yongxingfang & Theme park \\
\hline 19 & Tang Papadise & Landscape \\
\hline 20 & City wall & Cultural relics \\
\hline 21 & City Moat & Cultural relics \\
\hline
\end{tabular}

\subsection{Mapping Landscape Aesthetics Flow}

Photographs from Flickr were used to assess the LA flow. Flickr is an image and video hosting website. The landscape photos uploaded to the Flickr platform were of landscape considered aesthetically pleasing. Herein, the photos of Xi'an in Flickr from 2017 to 2018 were analyzed to assess the LA flow. There is a total of 10,278 photographs in this dataset. Photographs were discarded if they did not represent a landscape feature or the correct geographical location. The discard details are as follows: 1) the photos were located in the wrong place or outside of Xi'an; 2) people, pets or developed environments were the main subject; 3 ) the photos were taken indoors; 4) the photographs did not relate to the landscape; 5) the photographs could not be identified or were not available; 6) the photos were copied or uploaded repeatedly. The final subsample of 1812 relevant photographs was selected and mapped onto a $200 \times 200 \mathrm{~m}$ resolution grid. The mapping was carried out with an ArcGIS software according to the following Equation (1):

$$
f_{i}=\sum_{i} p_{i}
$$


where $f_{i}$, the flow in cell $i$, is the total photographs in cell $i$, and $p$ is the photo number.

To examine the landscape diversity and research the LA flow related to landscape complexity, the coexistence of landscape features in the photographs was calculated according to the following Equation (2):

$$
E_{i j}=\frac{\text { Total } p_{j}}{\text { Total } p_{i}} \times 100
$$

where $E_{i j}$ is the coexistence value, total $p_{j}$ is the photographs representing the landscape feature $j$ among the landscape feature $i$, total $p_{i}$ is the total photographs of the landscape feature $i$.

\subsection{Mapping Landscape Aesthetics Capacity}

The LA capacity was studied with criterion weights that represent the impact of single landscape features on the LA capacity. These criterion weights were determined to calculate the value of landscape features. A survey was conducted in which respondents were asked to rank landscape features. The criterion weights were calculated according to a landscape aesthetic model (Kerebel et al., 2019). The values of the LA capacity were mapped onto a $200 \times 200 \mathrm{~m}$ grid. The value expressing the LA capacity was obtained according to the following Equation (3):

$$
C_{i}=\sum_{n}^{N}\left(v_{n, i} \times w_{n}\right)
$$

where $N$ is the total number of landscape features in cell $i, V_{n, i}$ is the visibility ( 1 = visible; $0=$ invisible) of landscape feature $n$ in cell $i$, and $w_{n}$ is the value of the criterion weight assigned to landscape feature $n$.

\subsection{Comparison between LA Flow and LA Capacity}

Various landscapes are located in different districts or counties of Xi'an. To enhance the planning and management of Xi'an, the spatial distribution of the LA flow and LA capacity was studied. The LA flow related to a district or county was calculated using the following Equation (4):

$$
f_{i}=\frac{\sum p_{i}}{A_{i}}
$$

where $f_{i}$ is the LA flow in the district (or county) $i$, and $A_{i}$ is the surface area of district (or county) $i$.

Furthermore, the LA capacity related to a district or county was calculated according to Equation (5):

$$
C_{i}=\frac{\sum_{n}^{N}\left(v_{n} \times w_{n}\right)_{i}}{A_{i}}
$$

The LA flow and LA capacity were divided into four groups, from the lowest to highest values. Four combinations (low-low, low-high, high-low and high-high) were used to compare the LA flow and LA capacity. 


\section{Results and Discussion}

\subsection{LA Flow Analysis}

Xi'an, with the fast-growing industries and city expansions, is located in the Guanzhong Basin, and there are 11 districts and 2 counties within its jurisdiction. The landscapes of Xi'an that were found in the Flickr photographs are located in the districts of Lianhu, Xincheng, Beilin, Yanta, Lintong and Chang'an (Figure 1). There are rich historical and cultural heritage features in these districts. Figure 2 shows the strong imbalance of the LA flow of Xi'an. Very high levels of LA flow exist in the districts of Lianhu, Xincheng, Beilin, Yanta ans Lintong. A total of $43.5 \%$ of the photographs are of the famous Terracotta Warriors of Qinshihuang's Mausoleum in the district of Lintong. The Emperor Qinshihuang's Mausoleum Site Museum is regarded as one of the iconic global heritage sites. There are 6.8 million and 8.5 million tourists visiting the terracotta warriors in 2017 and 2018, respectively (available online:

http://www.bmy.com.cn/html/gov/xw/bwgyw/bd2bc231169a47009c65431a0fcb7 d81.html). The City Wall and the Bell Tower of the Ming dynasty are located in three districts (Lianhu, Xincheng and Beilin), and ranked second and fourth, with $16.2 \%$ and $7.1 \%$ of the photos, respectively. These distinguished historical heritage sites attract a large number of tourists. The fountain had the third largest representation and was featured in $8.3 \%$ of the photographs. Footpaths, including Muslim Street, were present in $6.3 \%$ of the photos. It is clear that most landscapes are distributed in the main urban area of Xi'an. Langemeyer et al. (2018) used Flickr photographs to examine and map spatial distribution of the LA in Barcelona of Spain. They found that the high levels of the LA flows in urban landscapes of Barcelona were due to the interaction between developed infrastructure and other more "natural" landscape features. Complex landscape

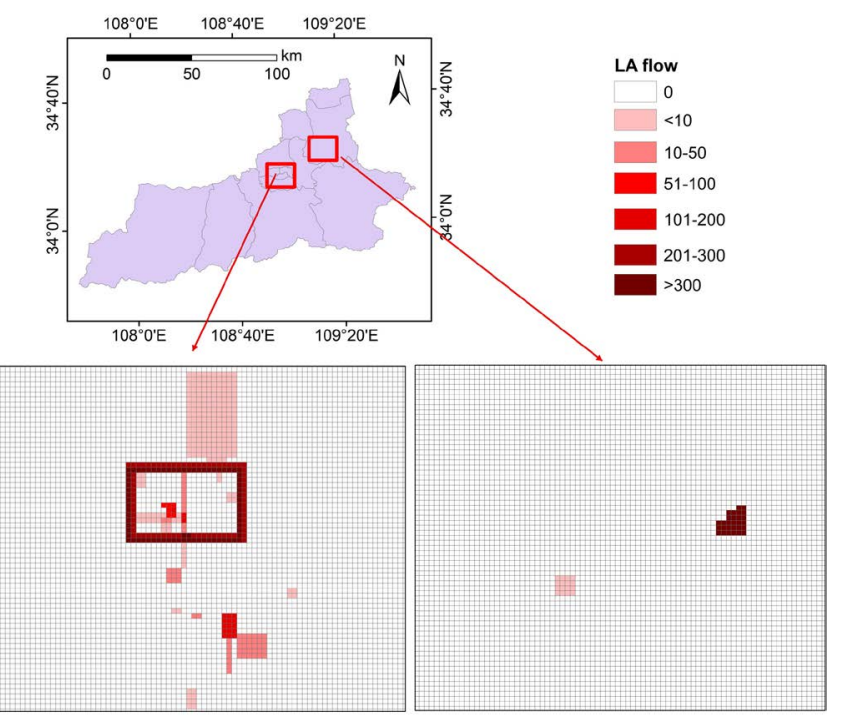

Figure 2. Landscape aesthetic flow in Xi'an. (The sum photographs at the $200 \times 200 \mathrm{~m}$ pixel level). 
features can enhance LA flow. In Barcelona, the built-infrastructure appears in association with other landscape features. Xi'an is qualitatively different from Barcelona in many ways, including its history, culture, landforms, recreation and inspiration. Table 2 shows that most landscapes of Xi'an include the built-infrastructure features. Xi'an has developed by humans for 1000 years and has an abundance of cultural heritage sites (72 imperial tombs and over 700 ancient buildings). Six historical sites are included in the "World Heritage List" (the terracotta warriors, Giant Wild Goose Pagoda, Small Wild Goose Pagoda, Daming Palace, Weiyang Palace, and Pagoda of Xingjiao Temple). Thus, LA values of Xi'an are associated with cultural heritage sites.

Table 2. The landscape characterizations of Xi'an based on Flickr photographs from 2017 to 2018 .

\begin{tabular}{|c|c|c|c|c|c|}
\hline $\begin{array}{l}\text { Landscape } \\
\text { feature class }\end{array}$ & & Landscape feature & $\begin{array}{c}\text { Occurrence \% } \\
\text { (Photograph } \\
\text { number) }\end{array}$ & Rank & $\begin{array}{c}\text { Criteria } \\
\text { weights } \\
(\%)\end{array}$ \\
\hline \multirow{25}{*}{$\begin{array}{l}\text { Built-infrastructure } \\
\text { features }\end{array}$} & \multirow{5}{*}{ Museum } & $\begin{array}{l}\text { Emperor Qinshihuang's } \\
\text { Mausoleum Site Museum }\end{array}$ & $43.5(789)$ & 1 & 7.1 \\
\hline & & Shaanxi History Museum & $0.6(11)$ & 6 & 3.3 \\
\hline & & Stele Forest Museum & $0.2(4)$ & 17 & 1.6 \\
\hline & & Xi'an Museum & $0.2(3)$ & 15 & 1.2 \\
\hline & & $\begin{array}{l}\text { Guanzhong Folk } \\
\text { Art Museum }\end{array}$ & $0.1(2)$ & 22 & 0.7 \\
\hline & \multirow{8}{*}{$\begin{array}{l}\text { Monumental } \\
\text { building }\end{array}$} & City wall & $16.2(293)$ & 3 & 6.9 \\
\hline & & Daming Palace & $0.2(3)$ & 8 & 1.2 \\
\hline & & Bell Tower & $7.1(129)$ & 2 & 6.6 \\
\hline & & Drum Tower & $3.7(67)$ & 9 & 5.8 \\
\hline & & Hua Qing Palace & $0.3(6)$ & 5 & 2.1 \\
\hline & & Small Wild Goose Pagoda & $2.3(41)$ & 10 & 5.0 \\
\hline & & Giant Wild Goose Pagoda & $4.3(78)$ & 4 & 6.1 \\
\hline & & Shuyuan Gate & $0.5(9)$ & 21 & 2.9 \\
\hline & \multirow{6}{*}{ Temple } & GuangRen Lama Temple & $0.3(6)$ & 25 & 2.4 \\
\hline & & Ci'en Temple & $0.6(11)$ & 11 & 3.3 \\
\hline & & Qinglong Temple & $0.1(2)$ & 14 & 0.7 \\
\hline & & Ancient Guanyin Monastery & $0.4(7)$ & 16 & 2.6 \\
\hline & & Daxingshan Temple & $0.06(1)$ & 26 & 0.3 \\
\hline & & Great Mosque of Xi'an & $3.6(65)$ & 27 & 5.6 \\
\hline & & Roads & $3.1(57)$ & 23 & 5.3 \\
\hline & & Footpaths & $6.3(115)$ & 19 & 6.3 \\
\hline & & Buildings & $0.7(13)$ & 20 & 3.7 \\
\hline & & Sculpture & $0.9(16)$ & 24 & 4.2 \\
\hline & & Park & $1.7(31)$ & 7 & 4.5 \\
\hline & & Yongxingfang & $0.3(5)$ & 12 & 1.9 \\
\hline \multirow{2}{*}{ Water features } & & City Moat & $1.8(33)$ & 13 & 4.8 \\
\hline & & Fountain & $8.3(15)$ & 18 & 4.0 \\
\hline
\end{tabular}


The use of landscapes as a touristic resource is beneficial for the creation of new prospects for sustainable development, and tourism is a flourishing industry and a key driver of the economy. In 2017, the number of tourists and the total tourism earnings in Xi'an were 180 million and 163 billion Chinese yuan, respectively (Xi'an Statistical Yearbook, 2018). Tourism promoted the development of the economy of Xi'an. Furthermore, it has been shown that the number of days the average international tourists stayed in Xi'an remained at 2.9 from 2004 to 2017. The time spent in Xi'an can be used to analyze tourist movements. Tourist movements can be identified as the behavior of a tourist from a place of origin to certain destinations. The number of photographs represents the popularity of attractions. Understanding the spatial distribution of the popularity of the attractions can help to identify tourists' preferences for visiting various sites. The results show that the tourist movements in Xi'an aggregated in specific sites. According to Table 2, it is obvious that a large number of tourists were attracted by the historical heritage sites. The aesthetic landscape values are high mainly in the site of terracotta warriors and City Wall. However, historical heritage sites do not compel tourists to stay very long. These results can be provided to policymakers to improve the sustainable interaction of tourism development in Xi'an. Policymakers can use the cultural resources of Xi'an to enhance the attractiveness of cultural relics by integrating resources and supervising personnel services (Zhao et al., 2018).

Moreover, heritage sites can provide attractive activities for tourists, such as historical reconstitutions, historical event reenactments and festivals. Generally, landscape features can appear in different combinations. The coexistence between landscape features was analyzed from the photographs of Xi'an on Flickr (Table 3 ). Table 3 shows that monumental buildings occur more frequently

Table 3. Coexistence between the landscape features of Xi'an.

\begin{tabular}{|c|c|c|c|c|c|c|c|c|c|c|c|}
\hline & $\begin{array}{c}\text { Museum } \\
(\%)\end{array}$ & $\begin{array}{l}\text { Monumental } \\
\text { building (\%) }\end{array}$ & $\begin{array}{c}\text { Temple } \\
(\%)\end{array}$ & $\begin{array}{c}\text { Roads } \\
(\%)\end{array}$ & $\begin{array}{l}\text { Footpaths } \\
(\%)\end{array}$ & $\begin{array}{c}\text { Building } \\
\text { (\%) }\end{array}$ & $\begin{array}{c}\text { Sculpture } \\
(\%)\end{array}$ & $\begin{array}{c}\text { Park } \\
(\%)\end{array}$ & $\begin{array}{c}\text { Modern } \\
\text { tourist } \\
\text { spot }(\%)\end{array}$ & $\begin{array}{c}\text { City } \\
\text { moat } \\
(\%)\end{array}$ & $\begin{array}{c}\text { Fountain } \\
(\%)\end{array}$ \\
\hline Museum & 100 & 5.1 & 0 & 0 & 0 & 0 & 1.0 & 0 & 0 & 0 & 0.37 \\
\hline Monumental building & & 100 & 1.8 & 0 & 2.4 & 0 & 0 & 0 & 0 & 5.3 & 1.4 \\
\hline Temple & & & 100 & 0 & 0 & 0 & 0 & 0 & 0 & 0 & 9.8 \\
\hline Roads & & & & 100 & 14 & 12 & 11 & 0 & 0 & 58 & 0 \\
\hline Footpaths & & & & & 100 & 1.7 & 1.7 & 0 & 0 & 0 & 0 \\
\hline Building & & & & & & 100 & 0 & 0 & 0 & 0 & 0 \\
\hline Sculpture & & & & & & & 100 & 0 & 0 & 0 & 0 \\
\hline Park & & & & & & & & 100 & 0 & 0 & 0 \\
\hline Modern tourist spot & & & & & & & & & 100 & 0 & 0 \\
\hline City Moat & & & & & & & & & & 100 & 0 \\
\hline Fountain & & & & & & & & & & & 100 \\
\hline
\end{tabular}


than other landscape features. Roads, parks and modern tourist spots remain as the individual features that sustain the LA flow. The coexistence of landscape features is relatively low in Xi'an due to the distribution of heritage sites. To enhance the landscape complexity of Xi'an, officials making land use policies should consider the significant differences in the area, activity degree, and transfer mode of lands with different tourism purposes (Liu et al., 2018).

The development of the tourism industry requires a variety of functional spaces, such as site for transportation, accommodation, catering, sightseeing, shopping and entertainment. The attractions are mainly located in the core zone of Xi'an, and the transportation and accommodation services become saturated in the districts of Lianhu, Beilin, Xincheng and Yanta. With the rapid urbanization of Xi'an, officials should account for changes in the spatial distribution of functional spaces by developing the tourism industry in the suburban districts/counties.

\subsection{LA Capacity Analysis}

The LA-capacity of Xi'an was investigated to inform the spatial multicriteria analysis (Figure 3 ). The LA-capacity was deeply influenced by the historical and cultural elements of Xi'an. Although the distribution of the LA-capacity is unbalanced, there are two or more landscape features in the districts of Lianhu, Beilin, Yanta, Xincheng and Lintong. It is obvious that the built-infrastructure features are seriously impacted by the museum and historical monumental buildings. The water features are limited by geographical and historical factors. There are eight rivers and streams (Wei River, Jing River, Chan River, Ba River, Jue River, Lao River, Hao River and Feng River) surrounding Xi'an. In particular, the Wei River has had a significant impact on Chinese civilization. The most popular of water features are City Moat and the fountain in the north square of

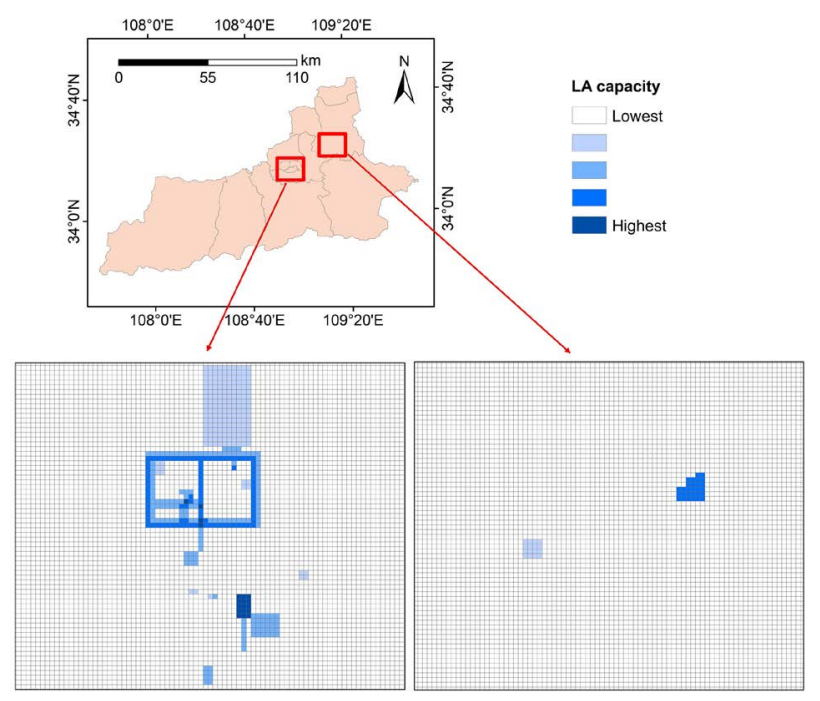

Figure 3. Landscape aesthetic capacity in Xi'an. (The sum photographs at the $200 \times 200$ m pixel level). 
the Giant Wild Goose Pagoda. However, the natural landscape features in Xi'an are not very popular.

LA values contribute substantially to attracting visitors and enhancing socioeconomic well-being. LA, i.e. the understanding of beauty by human cognitive perception, consists of visual aesthetics formed by the appearance of the physical landscape (natural and man-made features developed in the landscape) and sensed aesthetics formed by human sensory perception (smell, sound, taste and touch) (Lazdāne et al., 2013). The intangible cultural heritage of Xi'an can be a "living bridge", linking aspects of cultural history and traditions; this is an important element of any destination's tourism resources. However, the visual landscapes are aggregated on some physical heritage resources. The landscape diversity of Xi'an tends to be homogenous. Landscape diversity is an important aspect of biodiversity (Noss, 1990) and consists of cultural and natural elements, considering the diversity of land uses, and structures and forms (Haber et al., 2008). To enforce and develop landscape diversity, local authorities should learn about tourists' preferences to increase the diversity of touristic attractions by promoting other natural and cultural landscape values beyond recreation. An increase in landscape diversity would result in an increase in the city scale and land use change, and a decrease in cultivated land. Moreover, tourist movements can be enriched, and the spent time in Xi'an could be increased owing its complex landscape diversity. Scientific and technological advancements can be used to create new forms of landscape aesthetics to enhance the image of Xi'an as a domestic and international tourism destination. The project of "Eight Rivers Regeneration" has been programmed to restore sustainable water management in Xi'an. Some waterfront parks will be engineered to mimic the landscape design of the tang dynasty according to ancient illustrations. The project will take advantage of diverse sources of natural precipitation, such as streams and reclaimed water, and build a quasi-natural urban water cycle. Furthermore, the engineering will lead to the perfect combination of water resources and attractive landscapes.

\subsection{Comparison between LA Flow and LA Capacity}

The comparison of the spatial distributions of LA flow and LA capacity in Xi'an is shown in Figure 4. The highest LA flow and LA capacity are observed in the districts of Lianhu and Beilin districts, and in Beilin, respectively. The district of Lintong shows high LA flow and low LA capacity due to its few landscape sites (the terracotta warriors and Huaqing Palace). The highest LA flow capacity appears around the core area of Xi'an, including the district of Lianhu, Beilin and Xincheng. There are many museums and historical viewpoints distributed in these districts. High-low-grade LA flow capacity is observed in the Yanta district, with some urban landscapes, such as parks, squares and footpaths. Unfortunately, other districts remain in a low grade of LA flow capacity. The districts/counties of Zhouzhi, Huyi and Lantian are located in the northern foothills 

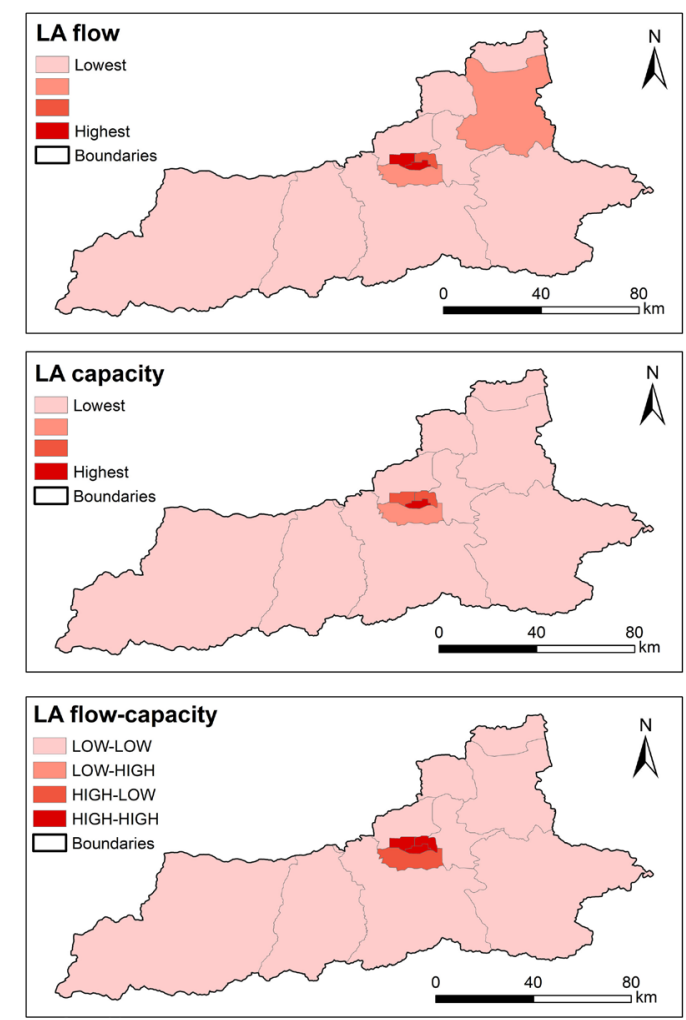

Figure 4. Comparison between LA flow and LA capacity.

of Qinling Mountain; however, they do not have any mountainous and natural landscapes. In high LA flow and LA capacity areas, a new development in the landscape cannot be accommodated without a significant and adverse impact on the landscape character. A small-scale development can be implemented, but the setting and form of the existing features and the characteristics and sensitivity of the adjacent areas should be considered. The low LA flow and LA capacity areas can accommodate larger amounts of development, although certain landscapes and visual features need protection.

It is obvious that the landscape sites are mainly gathered in the urban core zone of Xi'an. High-density landscapes can benefit city sustainability by reducing travel time and improving energy efficiency (Belchera et al., 2019). Cultural services can reach their upper limits in long-term high-density landscape areas. Therefore, high-density areas can show a decreased quality of life due to the social imbalances characterizing large cities. However, LA is the outcome of interactions between humans and landscapes. The demand for aesthetically pleasing natural landscapes has increased with an increase in urbanization (Sarukhán \& Whyte, 2005). Furthermore, the quantity and quality of high-density landscape areas contributing to landscape aesthetics are declining (Frank et al., 2013). To ensure the sustainability of cities, future urban planning strategies should consider mechanisms for coping with different types of land use conflicts (Gavrilidis et al., 2016) address the conflict between ecological sustainability and environmental aesthetics. 


\subsection{Limitation and Future Direction}

Based on economics and the resources of the information age, in situ social media data is a very attractive information resource related to cultural ecosystem services and can be used to examine LA flow. Landscape photographs contain the significant information on human relationships with landscapes, human practices in landscapes and landscape features (Oteros-Rozas et al., 2018).

Precise methods are needed to efficiently obtain information from and analyze the contents of landscape photographs. The relationships between human activity and landscape aesthetics can be investigated using analysis of social media data. Furthermore, the relationships between cultural ecosystem services and landscape features can be explored by combining the land use policies.

Social media data, which are freely and easily available from internet, are relatively inexpensive and less time consuming to collect than extensive surveys. The visual evidence demonstrates what people appreciate at each location and offers a qualitative insight into the concentrations of unexplained variation in the tourist patterns (Tieskens et al., 2018). Photographs from Flickr with geotagged data can be used to identify popular viewpoints in landscapes and understand landscape aesthetics in a spatial context (Chen et al., 2018). In this study, all the photographs of Xi'an from Flickr (2017-2018) were acquired, and less than one fifth-of them were selected for this work. Using these social media data is a novel approach to expand the assessment of LA and estimate the LA-flow from multiple observations in a spatially explicit form and across large scales. This method has the benefit of avoiding the participatory photography or social surveys used by many conventional studies to collect quality data. Comparable data from different social media sites, such as Flickr or Instagram, can be obtained to study different regions of the world. This can help researchers to compare multiple types of landscape features and more easily understand LA and land use policy. In this study, some places were visited less frequently due to incomplete demographic information in the social media data, and their LA values are difficult to express accurately. Therefore, gaps or blank spots may exist in this research. Future research will build automated models to analyze photograph contents and reduce manual work. This will allow us to analyze much larger samples and improve the data validity and reliability by efficiently extracting information from social media data, helping to establish a comprehensive database for the assessment of LA.

\section{Conclusion}

In this work, a methodological approach was developed to model their spatial distribution and quantify the appreciation and characterization of the structural elements of a landscape. Social media data, particularly photographs, provide a useful source for quantifying and mapping LA flow and LA capacity at the regional scale. This tool demonstrates that the crow-sourced geospatial data can be valuable for analyzing LA. The use of social media data is in its infancy and has 
potential limitations; nevertheless, these data were used to explore the intangible values related to individuals, society and culture Xi'an, China. This research provides a spatial analysis method to understand LA and make LA assessment more operational and provides evidence supporting the integration of LA into land use policies and landscape planning.

\section{Conflicts of Interest}

The authors declare no conflicts of interest regarding the publication of this paper.

\section{References}

Baró, F., Palomo, I., Zulian, G., Vizcaino, P., Haase, D., \& Gómez-Baggethun, E. (2016). Mapping Ecosystem Service Capacity, Flow and Demand for Landscape and Urban Planning: A Case Study in the Barcelona Metropolitan Region. Land Use Policy, 57, 405-417. https://doi.org/10.1016/j.landusepol.2016.06.006

Belchera, R. N., Suen, E., Menz, S., \& Schroepfer, T. (2019). Shared Landscapes Increase Condominium Unit Selling Price in a High-Density City. Landscape and Urban Planning, 192, Article ID: 103644. https://doi.org/10.1016/j.landurbplan.2019.103644

Chen, Y., Parkins, J. R., \& Sherren, K. (2018). Using Geo-Tagged Instagram Posts to Reveal Landscape Values around Current and Proposed Hydroelectric Dams and Their Reservoirs. Landscape and Urban Planning, 170, 283-292.

https://doi.org/10.1016/j.landurbplan.2017.07.004

Cui, Y., Meng, C., He, Q., \& Gao, J. (2018a). Forecasting Current and Next Trip purpose with Social Media Data and Google Places. Transportation Research Part C, 97, 159-174. https://doi.org/10.1016/j.trc.2018.10.017

Cui, Y., Xie, X., \& Liu, Y. (2018b). Social Media and Mobility Landscape: Uncovering Spatial Patterns of Urban Human Mobility with Multi Source Data. Frontiers of Environmental Science \& Engineering, 12, 7. https://doi.org/10.1007/s11783-018-1068-1

Dupras, J., Laurent-Lucchetti, J., Revéret, J.-P., \& DaSilva, L. (2018). Using Contingent Valuation and Choice Experiment to Value the Impacts of Agri-Environmental Practices on Landscapes Aesthetics. Landscape Research, 43, 679-695.

https://doi.org/10.1080/01426397.2017.1332172

Estruch-Guitart, V., \& Vallés-Planells, M. (2015). The Role of Landscape Aesthetics in the Total Economic Value of Landscape: A Case Study of Albufera Natural Park. WIT Transactions on Ecology and the Environment, 192, 219-230.

https://doi.org/10.2495/ECO150201

Figueroa-Alfaro, R. W., \& Tang, Z. (2017). Evaluating the Aesthetic Value of Cultural Ecosystem Services by Mapping Geo-Tagged Photographs from Social Media Data on Panoramio and Flickr. Journal of Environmental Planning and Management, 60, 266-281. https://doi.org/10.1080/09640568.2016.1151772

Frank, S., Fürst, C., Koschke, L., Witt, A., \& Makeschin, F. (2013). Assessment of Landscape Aesthetics-Validation of a Landscape Metrics-Based Assessment by Visual Estimation of the Scenic Beauty. Ecological Indicators, 32, 222-231.

https://doi.org/10.1016/j.ecolind.2013.03.026

Gavrilidis, A. A., Ciocănea, C. M., Niță, M. R., Onose, D. A., \& Năstase, I. I. (2016). Urban Landscape Quality Index-Planning Tool for Evaluating Urban Landscapes and Improving the Quality of Life. Procedia Environmental Sciences, 32, 155-167. 
https://doi.org/10.1016/j.proenv.2016.03.020

Ginzarly, M., Roders, A. P., \& Tellera, J. (2019). Mapping Historic Urban Landscape Values through Social Media. Journal of Cultural Heritage, 36, 1-11. https://doi.org/10.1016/j.culher.2018.10.002

Gobster, P. H., Nassauer, J. I., Daniel, T. C., \& Fry, G. (2007). The Shared Landscape: What Does Aesthetics Have to Do with Ecology? Landscape Ecology, 22, 959-972. https://doi.org/10.1007/s10980-007-9110-x

Haber, W. (2008). Biological Diversity a Concept Going Astray? GAIA-Ecological Perspectives for Science and Society, 17, 91-96. https://doi.org/10.14512/gaia.17.S1.4

Howley, P. (2011). Landscape Aesthetics: Assessing the General Publics' Preferences towards Rural Landscapes. Ecological Economics, 72, 161-169. https://doi.org/10.1016/j.ecolecon.2011.09.026

Jorgensen, A. (2011). Beyond the View: Future Direction in Landscape Aesthetics Research. Landscape and Urban Planning, 100, 353-355. https://doi.org/10.1016/j.landurbplan.2011.02.023

Kerebel, A., Gélinas, N., Déry, S., Voigt, B., \& Munson, A. (2019). Landscape Aesthetic Modelling Using Bayesian Networks: Conceptual Framework and Participatory Indicator Weighting. Landscape and Urban Planning, 185, 258-271. https://doi.org/10.1016/j.landurbplan.2019.02.001

Kong, F., Yin, H., \& Nakagoshi, N. (2007). Using GIS and Landscape Metrics in the Hedonic Price Modeling of the Amenity Value of Urban Green Space: A Case Study in Jinan City, China. Landscape Urban Planning, 79, 240-252.

https://doi.org/10.1016/j.landurbplan.2006.02.013

Langemeyer, J., Calcagni, F., \& Baró, F. (2018). Mapping the Intangible: Using Geolocated Social Media Data to Examine Landscape Aesthetics. Land Use Policy, 77, 542-552. https://doi.org/10.1016/j.landusepol.2018.05.049

Lazdāne, L., Jankevica, M., \& Zigmunde, D. (2013). Diversity of Landscape Aesthetics in Rural, Periurban and Urban Ecosystems. Mokslas-Lietuvos Ateitis/Science-Future of Lithuania, 5, 229-241. https://doi.org/10.3846/mla.2013.40

Lee, S.-H., \& Son, Y.-H. (2018). Identifying Landscape Perceptions of Visitors' to the Taean Coast National Park Using Social Media Data-Focused on Kkotji Beach, Sinduri Coastal Sand Dune, and Manlipo Beach. Journal of the Korean Institute of Landscape Architecture, 46, 10-21. https://doi.org/10.9715/KILA.2018.46.5.010

Liu, J., Wang, J., Wang, S., Wang, J., \& Deng, G. (2018). Analysis and Simulation of the Spatiotemporal Evolution Pattern of Tourism Lands at the Natural World Heritage Site Jiuzhaigou, China. Habitat International, 79, 74-88. https://doi.org/10.1016/j.habitatint.2018.07.005

Nogué, J., \& Vicente, J. (2004). Landscape and National Identity in Catalonia. Political Geography, 23, 113-132. https://doi.org/10.1016/j.polgeo.2003.09.005

Noss, R. F. (1990). Indicators for Monitoring Biodiversity: A Hierarchical Approach. Conservation Biology, 4, 355-364. https://doi.org/10.1111/j.1523-1739.1990.tb00309.x

Oteros-Rozas, E., Martín-López, B., Fagerholm, N., Bieling, C., \& Plieninger, T. (2018). Using Social Media Photos to Explore the Relation between Cultural Ecosystem Services and Landscape Features across Five European Sites. Ecological Indicators, 94, 74-86. https://doi.org/10.1016/j.ecolind.2017.02.009

Pastur, G. M., Peri, P. L., Lencinas, M. V., García-Llorente, M., \& Martìn-Lopez, B. (2016). Spatial Patterns of Cultural Ecosystem Services Provision in Southern Patagonia. Landscape Ecology, 31, 383-399. https://doi.org/10.1007/s10980-015-0254-9 
Plieninger, T., Dijks, S., Oteros-Rozas, E., \& Bieling, C. (2013). Assessing, Mapping and Quantifying Cultural Ecosystem Services at Community Level. Land Use Policy, 33, 118-129. https://doi.org/10.1016/j.landusepol.2012.12.013

Poder, T., Dupras, J., Ndefo, F., \& He, J. (2016). The Economic Value of the Greater Montreal Blue Network (Quebec, Canada): A Contingent Ranking Study to Estimate Non Market-Aquatic Ecosystem Services Benefits. PLoS ONE, 11, e0158901. https://doi.org/10.1371/journal.pone.0158901

Richards, D. R., \& Friess, D. A. (2015). A Rapid Indicator of Cultural Ecosystem Service Usage at a Fine Spatial Scale: Content Analysis of Social Media Photographs. Ecological Indicators, 53, 187-195. https://doi.org/10.1016/j.ecolind.2015.01.034

Saito, Y. (2007). Everyday Aesthetics. Oxford: Oxford University Press. https://doi.org/10.1093/acprof:oso/9780199278350.001.0001

Sarukhán, J., \& Whyte, A. (2005). Millennium Ecosystem Assessment. Ecosystems and Human Well-Being: Synthesis. Washington DC: Island Press.

Schirpke, U., Altzinger, A., Leitinger, G., \& Tasser, E. (2019). Change from Agricultural to Touristic Use: Effects on the Aesthetic Value of Landscapes over the Last 150 Years. Landscape and Urban Planning, 187, 23-35. https://doi.org/10.1016/j.landurbplan.2019.03.004

Spyrou, E., \& Mylonas, P. (2016). A Survey on Flickr Multimedia Research Challenges. Engineering Applications of Artificial Intelligence, 51, 71-91. https://doi.org/10.1016/j.engappai.2016.01.006

Tenkanen, H., Minin, E. D., Heikinheimo, V., Hausmann, A., Herbst, M., Kajala, L., \& Toivonen, T. (2017). Instagram, Flickr, or Twitter: Assessing the Usability of Social Media Data for Visitor Monitoring in Protected Areas. Scientific Reports, 7, Article No. 17615. https://doi.org/10.1038/s41598-017-18007-4

Tieskens, K. F., van Zanten, B. T., Schulp, C. J. E., \& Verburg, P. H. (2018). Aesthetic Appreciation of the Cultural Landscape through Social Media: An Analysis of Revealed Preference in the Dutch River Landscape. Landscape and Urban Planning, 177, 128-137. https://doi.org/10.1016/j.landurbplan.2018.05.002

van Riper, C. J., Kyle, G. T., Sutton, S. G., Barnes, M., \& Sherrouse, B. C. (2012). Mapping Outdoor Recreationists' Perceived Social Values for Ecosystem Services at Hinchinbrook Island National Park, Australia. Applied Geography, 35, 164-173.

https://doi.org/10.1016/j.apgeog.2012.06.008

van Zanten, B. T., van Berkel, D. B., Meetemeyer, R. K., Smith, J. W., Tieskens, K. F., \& Vergurg, P. H. (2016). Continental Scale Quatification of Landscape Values Using Social Media Data. Proceedings of the National Academy of Sciences of the United States of America, 113, 1-7. https://doi.org/10.1073/pnas.1614158113

van Zanten, B. T., Verburg, P. H., Koetse, M. J., \& van Beukering, P. J. H. (2014). Preferences for European Agrarian Landscapes: A Meta-Analysis of Case Studies. Landscape and Urban Planning, 132, 89-101. https://doi.org/10.1016/j.landurbplan.2014.08.012

Villamagna, A. M., Angermeier, P. L., \& Bennett, E. M. (2013). Capacity, Pressure, Demand, and Flow: A Conceptual Framework for Analyzing Ecosystem Service Provision and Delivery. Ecological Complexity, 15, 114-121.

https://doi.org/10.1016/j.ecocom.2013.07.004

Xi'an Statistical Yearbook (2018). http://tjj.xa.gov.cn/tjnj/2018/zk/indexch.htm

Yoshimura, N., \& Hiura, T. (2017). Demand and Supply of Cultural Ecosystem Services: Use of Geotagged Photos to Map the Aesthetic Value of Landscapes in Hokkaido. Ecosystem Services, 24, 68-78. https://doi.org/10.1016/j.ecoser.2017.02.009 
Zhang, H., Gao, Y., Hua, Y., Zhang, Y., \& Liu, K. (2019). Assessing and Mapping Recreationists' Perceived Social Values for Ecosystem Services in the Qinling Mountains, China. Ecosystem Services, 39, Article ID: 101006. https://doi.org/10.1016/j.ecoser.2019.101006

Zhao, X., Lu, X., Liu, Y., Lin, J., \& An, J. (2018). Tourist Movement Patterns Understanding from the Perspective of Travel Party Size Using Mobile Tracking Data: A Case Study of Xi'an, China. Tourism Management, 69, 368-383.

https://doi.org/10.1016/j.tourman.2018.06.026 